\section{JOMOPS}

JOURNAL OF MODERNISM AND POSTMODERNISM STUDIES

\title{
THE ETERNAL RESURRECTION OF MODERNITY
}

Rachad Chafik ELIDRISSI ${ }^{1}$

\begin{abstract}
In this paper, I reflect on the intertwined, shifting relationship among modernity, postmodernity, and liquid modernity by drawing from texts on philosophy, sociology, and theology. I present and argue three statements: 1) postmodernity is at once a rupture and continuity of modernity, 2) postmodernity is an epoch bridging the shift of society's conditions from solid to liquid form, and 3) liquid modernity characteristics overlap with hypermodernity rather than postmodernity. Within the consideration devoted to these statements, I posit that modernity is a concept that has an outstanding potential to perpetuate by relentlessly resurrecting itself under different forms.
\end{abstract}

Keywords: Neo-solidification, Liquid Modernity, Metanarratives, Fragmentation, Ambivalence, Demystification, Hypermodernity, Postmodernity.

\section{Introduction}

With the desire and permanent dynamic to go beyond the past, modern societies mark a "maelstrom of perpetual disintegration and renewal" (Berman 15), and forge an everlasting "new" which almost immediately ceases to be "new" once generated, and so forth. It is a relentless change, a restless form of thinking which does not proceed from or expect to reach a transcendental or transcendent ground or principle. The very essence of modern societies is what prevents them from settling and reaching stability. Their progress is always asymmetrical and unsteady, which is, hypothetically, due to the failure of humans to create a predictable and demystified world. Under the ungratified promises of emancipation and enhancement, what defines the modern remains changeable with continual alternatives that perpetually negate the ideologies of the past and carry on creating new ones. Against this background, societies have been on a rollercoaster of change, moving from modern to postmodern, and liquid modern conditions. This article finds its impetus in this intertwined, shifting relationship of these societal conditions. In the opening section, I will outline some characteristics of modernity in light of the sacralisation of man's idea and the concepts of grand narrative and metanarrative. I will proceed by declaring the fall of modernity and its resurrection into postmodernity and how these two narratives are connected. Next, I will discuss the

\footnotetext{
${ }^{1}$ PhD. Student, Department of Radio, Television and Cinema, Social sciences institute, el.idrissi.chafik@gmail.com, https://orcid.org/0000-0002-1332-1327.
} 
main points of convergence and divergence between "postmodernity" and "liquid modernity," and how this latter comes to overlap with the concept of "hypermodernity." Throughout the paper, I will emphasize the exceptional potential of modernity to strive by consistently resurrecting in various forms.

\section{The Shift in God's Status: The Nest of Modernity ${ }^{2}$}

The concept of modernity has been long debated by a wide range of scholars. In Frederic Jameson's words, "modernity is not a concept but rather a narrative category" (Jameson 94). It is at once a historical phase, a human-led movement for continuous progress and an ontological rupture. It is the result of an emancipatory impulse, a revolutionary rupture intended to be empowering and liberating within a tradition in decline. At its simplest, modernity is the rejection of traditional values, in particular the holistic pre-modern faith, driving the society gradually away from an omniscient and almighty God to absolute atheism. This negation of God's existence has, consequently, brought forth an unassailable belief in the physical world which will mark the beginning of decadence, moral decline, and inevitably the crisis of the modern world and meaning. ${ }^{3}$

God is dead. God remains dead. And we have killed him. How shall we comfort ourselves, the murderers of all murderers? What was holiest and mightiest of all that the world has yet owned has bled to death under our knives: who will wipe this blood off us? What water is there for us to clean ourselves? What festivals of atonement, what sacred games shall we have to invent? Is not the greatness of this deed too great for us? Must we ourselves not become gods simply to appear worthy of it? (Nietzsche 181)

Nietzsche's prominent declaration of "God's death" is a commentary and criticism of the age of Enlightenment, together with the rise of industrial capitalism and the modern nation which emphasized science and reason over faith and superstition. Casting "God" aside and putting the "man" at the center of everything, "there arises a

\footnotetext{
2 The famous Christian theologian Anselm of Canterbury (1033-1109) said: "I believe (in God) so that I may understand" (credo ut intelligam). This saying emphasizes the premodern dominant philosophy to the effect that God is the basis for absolute moral and rational truths, the origin and the starting point for knowledge and wisdom, and the supreme being through which the "man" can accurately interpret his world.

${ }^{3}$ Owing to the scientific discoveries and technological advances of the modern world, the "man" has gradually been bewitched and blinded by the achievements of his own made society and has, inevitably, begun to lose both interest and understanding of God and the spiritual self. In this sense, Frederic Nietzsche (1974) argued that the death of God was not the appearance, but rather the disappearance of man, that man and God have a dependency relationship, by the death of the creator (God) the creation (man) could not help but disappear as well.
} 
new faith, faith in humanity or liberty. For the individual's God, the God of all, namely, 'man', is now exalted; 'for it is the highest thing in us all to be man'” (Stirner 129). ${ }^{4}$ The modern age was the period when humans ceased turning toward the supernatural realm and began to root their faith in the concept of "man," as the master of his destiny, creating by that a new stage in human existence rationalized and (almost) demystified through which the man has become some mythical hero.

This enlightened anthropocentric view can be traced back to the Renaissance, wherein humanism thrived in identifying what distinguishes humans from other beings to support the principle of man's singularity. In the fifteenth century the Italian philosopher and theologian Giovanni Pico della Mirandola (1463-1494) wrote: "O great and wonderful happiness of man! It is given him to have that which he chooses and to be that which he wills" (5). With this representation of the "Renaissance man," Pico was the pioneer of the humanist myth of "self-made man," a man inclined to refine and elevate himself to transcendency, especially through the revival of ancient literature, philosophy, rhetoric, philology, etc.

\section{Skepticism Toward the Metanarratives: The Fall of Modernity}

The philosopher Merold Westphal (1995) sees that modernity is characterized by the search for an absolute certainty (in reference to René Descartes' philosophy), which is an uninterrupted quest to demystify the nature of existence and relentless research for answers to humankind existential angst and problems in every epoch (Danilo qtd. in Watfa 2011). Against this background, the modernists tried to invent metanarratives ${ }^{5}$ and grand narratives ${ }^{6}$ - without referring to God - to teach the principles of human dignity, freedom, morals, and progress.

\footnotetext{
${ }^{4}$ René Descartes (1596-1650) in his pursuit of knowledge has dived into a skeptical journey, determined to question everything He asserted that "skepticism" was a form of thinking: "I am thinking, therefore I am" (Cogito, ergo sum). Unwarily, Descartes' philosophy has replaced God's omniscience with human knowledge, a philosophical perception that will soon be fundamentally reflected in the Enlightenment movement, a period in which humankind was both optimistic about its potential and reason, but also skeptical about the authority of the Church and Christian principles. ${ }^{5}$ According to Lyotard, metanarratives are "a set of rules that determine the legitimacy of a particular form of narrative, [...] and provide the criteria that allow one to judge which ideas and statements are legitimate, true and ethical for each different form of narrative" (Malpas 37).

${ }^{6}$ Modernity's grand narratives, on the other hand, "produce systematic accounts of how the world works, how it develops over history, and the place of human beings within it" (Malpas 37). It introduces the progress of knowledge as an instrument to demystify the world to improve the human condition and emancipate him from prejudices, enslavement and superstitions.
} 
The account mentioned above suggests that the humanistic conception of the world was the same as the religious one. When religion has alleged man's nature to be divine, the humanists have alleged man's nature to be rational. Religion believes in the soul, afterlife, spirits, and immaterial things, while the humanists have faith in the state, society, common good, and material things. Hence, humankind has merely traded one fixed idea for another. In this sense, it was a question of time before the conflict between promises and results in modernity came to the surface; rather than emancipation, enhancement and progress, modernity become often associated with totalitarianism, oppression, and terror; just like Horkheimer and Adorno in their famous book Dialectic of Enlightenment wrote: "Enlightenment [...] has always aimed at liberating human beings from fear and installing them as masters. Yet the wholly enlightened earth is radiant with triumphant calamity" (1). That is to say, the emancipation of man has only been accomplished in conjunction with violence and domination: totalitarian regimes, World Wars, and a global capitalist system.

In its quest for a rational, technological, progressive, and governable social order, modernity has failed. Modernity was meant, through the development of knowledge, to help humankind understand the essence of its existence, improve its conditions and emancipate it from ignorance, enslavement, and inequality. However, rather than emancipation, it has brought slavery, and rather than liberation, we got alienation, a state of unfulfillment where the traditional social relations has been weakened and disintegrated - becoming predominantly and structurally based upon economics reduced to relations between things, and inevitably the relation between things has been elevated to the status of social relations. From this point of view, we are reminded of Ulrich Beck's definition of "modernization" in which he emphasized that it was a process not just limited to "technological rationalization and changes in work and organization," but it goes beyond that to include "the change in societal characteristics and normal biographies, changes in lifestyle and forms of love, change in the structures of power and influence, in the forms of political repression and participation, in views of reality and in the norms of knowledge" (Beck 50).

After a series of historical events, trust in science, human progress and emancipation were crushed on the rocks of mass atrocities crimes. The grand narratives of Marxism, scientism, or rationality tyrannized the "other." The metanarrative of science and technology unveiled its lack of humanity when put at the service of political ideology (e.g., the use of atomic bombs during WWII and the spray of dioxins during the Vietnam 
War). Thus, these grand narratives and metanarratives have proven to be total failures. The disastrous consequences of modernity have caused a general state of confusion and disorientation and unleashed a wave of uncertainty - humans have become hopelessly and desperately searching for alternatives - marking the beginning of a postmodern climate and giving rise to pluralism and fragmentation of narrative in the West.

\section{Modernity shed its skin: Postmodernity}

There is not a specific time in history that we can point to as a separating line between the two eras (modernity and postmodernity), and that is the nature of historical changes as all social conditions are the results of a succession of interrupted steady antecedents and prophetic historical events. Thus, the term "postmodernity" which Lyotard (1984) simply defines as skepticism towards metanarratives, remains until now as a concept highly debated, hard to understand, and even harder to define.

The positioning of "postmodernity" has been long debated as to whether it is a rupture of continuity of modernity. The prefix 'post-' can signify a "process of historical succession in which modernity and postmodernity follows on from and replaces the modern," or an entirely "cut off from everything that might have led up to it" (Malpas 42). In his essay "Note on the Meaning of "Post-" (1985), Lyotard brings forward three explanatory statements on the relationship between the modern and the postmodern:

(1) as a new period, style or fashion that supersedes earlier ones; [...] (2) moment at which innovation and development can no longer be equated with progress; [...] (3) the postmodern does not simply replace the modern, but rather performs a continual rereading and critique of modern values and projects. Postmodernity is not a new age, but rather the name for a collection of critiques that seek to challenge the premises of those discourses that have shaped modern experience. (Malpas 42-44)

In light of this analysis, postmodernity cannot be naively defined as a rupture or a continuity. Postmodernity is the consequence of modernity performance. It is at once a rupture and a continuity: (1) a rupture with the traditional discourses (rationality, science, progress) in opposition to which modernity establishes itself as a narrative to emancipate mankind from all subjugation, (2) and a continuity as postmodernity is not something isolated or separated from modernity. It is a concept that comes from 
modernity's womb and rises from the ashes of its failure. It can be said to be a rupture only if it stands on its self-constructed ideas, which is existentially and rationally impossible in a world where nothing can be created out of nothingness. Thus, the concept of postmodernity along with postmodernism exists because of the anterior existence of its predecessor, "modernity." They "incorporate that which they aim to contest by incorporating and remoulding the modernity within themselves" (Hutcheon 3). This suggests that postmodernity is a consequence of modernity (Giddens); it is at once a deviation from and a perpetuation of modernity.

All things considered, if modernity marked the triumph of metanarratives and grand narratives, postmodernity has dethroned them, giving place to an era of fragmentation and pluralism of narratives in which no single idea prevails and where a variety of ideas, however divergent and heterogeneous, can exist side-by-side. In one of his dialogues, Plato mentioned the Protagoras thinker "[t]hat as each thing appears to me, so it's for me, and as it appears to you so it's for you" (qtd. in Williams, Levett, and Burnyeat 14), his words encapsulate the postmodern philosophy wherein the one true ideology no longer rules.

\section{The Radicalism: Toward a Liquid Modernity or Hypermodernity}

Just as its precursor, the postmodern philosophy came to emancipate humankind, liberate it from the western mythology based on hegemony, exploitation, and westernization, by unveiling ideological delusions and undermining authoritarian rhetoric. This restless obsession with breaking free from the metanarratives and grand narratives of modernity has driven the human into an intensified fragmentation of narratives, giving place to a shift in society from a solid to a liquid form. In light of this, postmodernity can be evaluated and perceived as a phase of breathlessness and a starting point towards a total radicalism, which will unleash what Bauman terms "liquid modernity" (2006), a concept to which I stay true to its meaning but reevaluate its position as to what predated it historically.

As an alternative to "postmodernity," Bauman uses, equivalently, the term "liquid modernity," wherein he criticizes the modern trajectory stemming from the enlightenment philosophy, to show the impotence of societies to find in modernity a satisfactory balance for veritable emancipation. Liquid modernity defines and describes the condition of societies without a stable benchmark in which individuals are constantly brought to adapt to change, and it is a concept derivative of the era of globalization and 
the postmodern world wherein we witnessed the proliferation of doubt and confusion, the mushrooming of consumerism and mercantilism, and the demolition of social mores.

Through his work, Bauman puts "liquid modernity" in contrast to "solid modernity," in which stable and well-defined social forms exist. Prior to modernity, there were solid thoughts rooted mostly in the sacralization of the church, kings, and the supernatural world. Under these circumstances, modernity came as a movement to liquefy these solid thoughts by bringing the man out from its iron cage of tradition. However, this liquefaction was the starting point for a new moulding of the society, what I prefer to call "neo-solidification" with a reason as a means and perfection as a goal.

In light of the foregoing, postmodernity came as a counter-philosophy against this "neo-solidification," just as modernity did with the solid form of pre-modern traditions, postmodernity has, in its turn, appropriated "liquefaction" as a destructive weapon against the solid forms of modernity, marked by that the commencement of a relentless liquefaction. Historically speaking, if postmodernity was more or less unleashed post to World War II, I would roughly position the visibility of liquid modernity post to the 9/11 terrorist attacks and the appearance of the twenty-first-century political grand narrative 'War on Terrorism.' This historical positioning represents the "pivotal moment," the moment that indicates the debut of a new era, a new world order, and marks the world's entrance into a novel and radical phase, a liquid phase characterized by a "perpetual aspect of continuous and continuing, compulsive and obsessive modernization" (Bauman 31).

It is against this background that the idea of postmodernity can neither serve as an interpretation of our contemporary social conditions nor as an equivalent concept to liquid modernity. Towards this end, a repositioning of 'liquid modernity' concept can align with the emergent concept of 'hypermodernity' which defines a modernity "qualifiable as radical in its no longer having any sufficiently organized counter-powers, nor offering any credible alternative model" (Charles and Lipovetsky qtd. in Charles 392), and characterizes societies of excessiveness deprived of any alternative model and "built around the notion of risk" (Charles 390).

If the prefix "post-" can signify a process of historical succession, the prefix "hyper" encapsulates this impression that "we live in societies marked by a climate of immoderation, exacerbation, and forward-fleeing" (Charles 392). In this context, another key fact to remember is that similarly to postmodernity, hypermodernity is at once a 
rupture and a continuity of modernity. Sébastien Charles wrote, "if modernity is a system founded on the individual, democracy, the market, and science, who does not see these four principles still making up the heart of our societies today?" (392); however, inversely to the modernity's promises of happiness, progress, prosperity, emancipation, equality, and universal harmony, hypermodernity delivers us modernity deprived of those ingredients of excellence, impuissant to justify or control its own doings, a "radical modernity" characterized by:

the exacerbation and intensification of that modern logic by which human rights and democracy have been made into mandatory values, by the market having become a global economic reference system reaching the remotest places on the planet and invading every sphere of our existence, and by science as an only partly controllable instrument that now throws even the notion of humanity itself into question by opening the possibility of human cloning (Charles 392).

Simply put, hypermodernity is postmodernity suffocating under an excessive speed by technology and consumption, which typifies late-stage capitalism. This liquefaction and superfluity in all areas elucidate why instability, insecurity, and uncertainty are the terms that fittingly represent and portray hypermodern societies, societies that favor "competition, flexibility, mobility, and adaptability" instead of "permanence and stability" (Charles 393), all which characterize the Baumanian concept of liquid modern societies.

\section{Conclusion}

The birth of modernity, postmodernity, and liquid modernity was a revolutionary break, advocating emancipation under the tyranny of a tradition in putrefaction. Wherein modernity promoted utopianism, postmodernity popularized skepticism which inevitably unleashed uncertainty and consequently gave birth to liquid modernity. Thus, humankind sailed away from a rigid categorization (metanarratives and grand narratives) to fragmentation of narratives, leading to a restless interdependent process of solidification and liquefaction wherein narratives ended up being radically liquified. Throughout this process, modernity has proven itself to be a concept that has an outstanding potential to perpetuate by relentlessly resurrecting itself in different forms. 


\section{WORKS CITED}

Bauman, Zygmunt. Liquid Modernity. John Wiley \& Sons, 2006.

Beck, Ulrich. Risk Society: Towards a New Modernity. Trans. Mark Ritter. London: Sage Publication, 1992.

Berman, Marshall. Al/ that is solid melts into air: The experience of modernity. New York: Penguin Books, 1988.

Bhattacharya, Arpita, et al. "Understanding Pivotal Experiences in Behavior Change for the Design of technologies for Personal Wellbeing." Journal of biomedical informatics 79 (2018): 129-142.

Charles, Sébastien. "For a Humanism Amid Hypermodernity: From a Society of Knowledge to a Critical Knowledge of Society." Axiomathes 19.4 (2009): 389400.

Della Mirandola, Pico. On the Dignity of Man. Hackett Publishing, 1998.Web. 15 December 2020.

Giddens, Anthony. The Consequences of Modernity. Polity Press, 1996. Web. 05 February 2020.

Horkheimer, Max, Theodor W. Adorno. Dialectic of Enlightenment. Trans. Edmund Jephcott. London: Verso, 2002

Hutcheon, Linda. A Poetics of Postmodernism: History, Theory, Fiction. New York: Routledge, 2003.

Jameson, Fredric. A Singular Modernity: Essay on the Ontology of the Present. London: Verso, 2002.

Kumar, Krishan. From Post-industrial to Post-modern Society: New Theories of the Contemporary World. New York: John Wiley \& Sons, 2005.

Lyotard, Jean-François. The Postmodern Condition: a Report on Knowledge. Vol. 10. Minnesota: U of Minnesota Press, 1984.

Malpas, Simon. The Postmodern. London: Psychology Press, 2005.

Nietzsche, Friedrich Wilhelm. The Gay Science: With a Prelude in German Rhymes and an Appendix of Songs. Vol. 985. New York: Vintage, 1974.

Stirner, Max. The Ego and Its Own. London: Cambridge UP, 1995. 
Watfa, Ali Asaad. الـــــــاثة مابعد" [Postmodernity]. Almarefh Journal 572 (May 2011): 22-39. Web. 10 October 2020.

Westphal, Merold. "Postmodernism and Religious Reflection." International Journal for Philosophy of Religion, vol. 38, no. 1/3, 1995, pp. 127-143. JSTOR, www.jstor.org/stable/40020334.

Williams, Bernard, M. J. Levett, and Myles Burnyeat. Theaetetus. Indianapolis: Hackett Publishing, 1992.Web. 20 April 2020. 